\title{
Effect of progesterone on some reproductive performances in cattle
}

\author{
El-Sayed, M. G. ${ }^{1}$, Mohamed El-Diasty $^{2}$ and Hadeer A. Magdy ${ }^{2}$ \\ ${ }^{1}$ Department of Pharmacology Faculty of Vet. Med. Mansoura University. Egypt \\ ${ }^{2}$ Animal Health Research Institute, Mansoura Provincial Lab., Egypt
}

\begin{abstract}
Our experiment was conducted at a special dairy farm in Dakahlia Governorate between the periods (March -May 2018), This farm consisted of 400 Holestien cows; from the total of the animals only 210 lactating cows. The established experiment applied on 40 cows suffered from different types of anestrum detected by ultrasonography as follow (15 cows suffer from cystic ovary, 15 cows suffer from smooth inactive ovaries and 10 cows suffer from persist corpus luteum to study the effect of progesterone device insertion in dairy cattle and its effect in fertility. On day 0 , cattle at random stage of estrous cycle received controlled internal drug release vaginal insert (CIDR). We left the CIDR in the vagina for seven days as we inject PGF2 on day 6 and remove the CIDR on day 7, blood samples were collected from 25 animals at zero day, $3^{\text {rd }}, 7^{\text {th }}$ and $9^{\text {th }}$ day from the tail vein, and then we follow the estrous and detected the estrus cow for AI and apply ultrasonography for pregnancy diagnosis after 30 day from insemination From this study it was concluded that the use of progesterone for 7 days + i.m. injection of $\mathrm{PGF}_{2} \alpha$ in the $7^{\text {th }}$ day can applied to dairy cattle to restart ovarian activity and it is an effective treatment for different infertility cases like cystic ovarian disease, persist corpus luteum and smooth in active ovaries. Moreover present study provides evidence for the importance of prior exposure to progesterone for cows to express estrous behavior, increase number of pregnant animals and increase conception rate.
\end{abstract}

Keywords: Cows, progesterone, reproductive efficiency

\section{INTRODUCTION}

Reproductive failure is a major source of economic loss in the beef industry as the main source of income in the dairy herds is from the sale of milk and calves. The majority of this loss occurs because cows do not become pregnant during a defined breeding season. Therefore, the goal of any breeding program is to maximize the number of females that become pregnant. This means that fertility plays a major role in the success of any breeding program (Arthur, 2001; Perry, 2005).

Fertility is defined as the ability of normal cyclic animal to become pregnant in a defined breeding period, Moreover the reproductive objective in dairy cattle production is one calf by cow / year. It means that cows must get pregnant after artificial insemination, maintain the pregnancy, have parturition after 270 days approximately and wait for a period of 40 to 50 days to be successfully inseminated again. Nevertheless, this is not always attained and some cows must be reinseminated during repeated cycles due to some infertility problems (Pecsok et al., 1994; Plaizier et al., 1998; Ravikumar, 2013).

Estrus synchronization is the most important and widely applicable reproductive biotechnologies available for cattle. The major factor limiting optimum reproductive performance on many cattle farms is failure to detect cows in heat in a timely and accurate manner. Poor heat detection results in excessive number of days not pregnant (days open) which causes long calving intervals. The newer systems, termed timed breeding or appointment breeding or estrus synchronization programmed are designed so both the onset of heat (estrus) and ovulation are induced so cows can be inseminated at a specific time without heat detection. This program is done based on various hormones either natural or artificial like, prostaglandin $F 2 \alpha$, Gonadotropin Releasing hormone (GnRH) and progesterone (CIDR) for deferent protocol methods (Yizengaw, 2017).

The CIDR is an intravaginal progesterone insert, used in conjunction with other hormones to synchronize estrous in beef and dairy cows and heifers. The CIDR was developed in New Zealand and has been used for several years to advance the first pubertal estrus in heifers and the first postpartum estrus in cows, moreover CIDR has recently come to the forefront in various countries throughout the world not only for estrus synchronization but also for increase pregnancy rates and the treatment of postpartum anestrous and ovarian cyst in cattle (Lamb and Larson, 2005; Zaabel et al., 2009).

Furthermore, incorporation of the CIDR into a timed Al protocol improved pregnancy rates in anovulatory dairy and beef cows, moreover treatment of anovulatory cows with CIDR for $7 \mathrm{~d}$ improved detection of estrus, ovulation rate, and pregnancy rates and incorporation of a CIDR into a timed Al protocol using GnRH to induce ovulation improved pregnancy rates (Khalilzadeh et al., 2013). 
This work was planned to evaluate the efficacy of progesterone as controlled internal drug release (CIDR) in treatment of some infertility cases in dairy cattle.

\section{MATERIALS AND METHODS}

\subsection{Drugs:}

2.1.1. Progesterone: (Eazi-Breed CIDR insert containing $1.38 \mathrm{~g}$ of P4, Pfizer, Animal Health, New York,NY). Description: The major progestational steroid that is secreted primarily by the corpus luteum and the placenta. Progesterone acts on the uterus, the mammary glands, and the brain. It is required in embryo implantation, pregnancy maintenance, and the development of mammary tissue for milk production. Progesterone, converted from pregnenolone, also serves as an intermediate in the biosynthesis of gonadal steroid hormones and adrenal corticosteroids (Schumacher et al., 2004). Physical state: White powder (Saad and EL-Nabawy, 2013). Dose: Dairy: 1.38g progesterone/insert, Beef: $1.38 \mathrm{~g}$ progesterone/insert (Saad and EL-Nabawy, 2013). Rout of administration: intra vaginal (Saad and EL-Nabawy, 2013).

2.1.2. prostaglandin: PGF2 $\alpha$ : Cloprostenol (Estrumate, Schering-Plough Animal Health, USA). Description: Cloprostenol is synthetic form of PGF $2 \alpha$ and involves its all functions. This hormone quickly causes to decomposition of active luteinizing and rapid decline in progesterone. This luteinizing property of PGF2 $\alpha$ leads to a new follicular growth and back to estrus and normal ovulation (Cooper, 1981; Khodabandehloo et al., 2013). Physical state: aqueous solution (Saad and EL-Nabawy, 2013). Route of administration: intramuscular injection (Saad and ELNabawy, 2013). Dose: $2 \mathrm{ml}$ (Saad and EL-Nabawy, 2013).

\subsection{Animals and Experimental design:}

Our experiment was done at a special dairy farm in Dakahlia Governorate between the periods (March -May 2018).This farm consisted of 400 Holestien cows; from the total of the animals only 210 lactating cows. The established experiment applied on 40 cows suffered from different types of anestrum detected by ultrasonography as shown in Table (1).

From the farm record we detected the anestrous cows, we choosed 40 anestrous cows from the farm record then we diagnose each case using ultrasonography le as shown in, Table (5). On day 0 , cattle at random stage of estrous cycle received controlled internal drug release vaginal insert (CIDR) as follow, first we always wear latex or nitrile gloves to prevent exposure to progesterone and introducing contaminants into the vaginas of treated females and we wash the applicator with disinfectant between uses, and clean the area of the vulva thoroughly then we Put the body of the insert into the applicator, with the tail in the slot, apply lubricant to the tip, and position the insert with the tail on the underside of the applicator and curling down Open the labia and slide the applicator in at a slight upward angle, then depress the plunger and withdraw the applicator slowly. (It is possible to cut the excess tail so other cows are less likely to pull it out).

We left the CIDR in the vagina for seven days as we inject PGF2 on day 6 and remove the CIDR on day 7, and then we follow the estrous and detected the estrus cow for $\mathrm{Al}$ and apply ultrasonography for pregnancy diagnosis after 30 day from insemination

Table (1): Types of Anestrous cows under our experiment.

\begin{tabular}{|c|c|c|c|c|}
\hline & $\begin{array}{l}\text { Cystic } \\
\text { ovary }\end{array}$ & $\begin{array}{l}\text { Smooth } \\
\text { inactive } \\
\text { ovary }\end{array}$ & $\begin{array}{l}\text { Persist } \\
\text { corpus } \\
\text { luteum }\end{array}$ & Tot \\
\hline Number & 15 & 15 & 10 & 40 \\
\hline $\begin{array}{l}\text { Age of animal } \\
\text { year }\end{array}$ & 4-5 years & $5-6$ years & $\begin{array}{l}3.5-5 \\
\text { years }\end{array}$ & $3.5-5$ \\
\hline $\begin{array}{l}\text { Anestrous cowl } \\
\text { day }\end{array}$ & $90-110$ & $90-130$ & $110-130$ & $90-130$ \\
\hline
\end{tabular}

\subsection{Sampling:}

We collected blood sample without anticoagulant only from (25) cows from the total treated 40 cows, the serum was separated by centrifugation at 3000rpm for 15 minutes the sera were collected in $1.5 \mathrm{ml}$ Eppendroff tubes and kept frozen at $-20^{\circ} \mathrm{C}$ until assayed, then we measured progesterone concentration, $\mathrm{FSH}$ and $\mathrm{LH}$ in all samples.

IV- Kits for diagnosis: Progesterone enzyme immunoassay test kit. Bovine follicle-stimulating hormone (FSH) ELISA kit. Bovine luteinizing hormone (LH)ELISA kit.

\subsection{Statistical analysis:}

Data obtained in this study were statistically analyzed by one way (ANOVA), using SPSS computer program (version. 20). (SPSS, 2015)

\section{RESULTS}

Our experiment was studied the effect of progesterone device insertion in dairy cattle and its effect in fertility.

The results revealed that the level of FSH was significantly increased $\left(36.83 \pm 1.22^{*}\right)\left(55.83 \pm 1.29^{*}\right)$ after treatment with progesterone device in $3^{\text {rd }}$ and $7^{\text {th }}$ day respectively when compared with that at the beginning of treatment $(26.50 \pm$ 1.34) in the same groups, as shown in Table (2).

The results showed that the level of LH was significantly increased $\left(15.03 \pm 0.342^{*}\right)\left(15.73 \pm 0.30^{*}\right)\left(22.70 \pm 0.55^{*}\right)$ after treatment with progesterone device in the $1^{\text {st }}, 3^{\text {rd }}$ and $9^{\text {th }}$ day respectively compared to control group as shown in Table (3). 
The results showed that the level of progesterone was significantly increased $\left(37.26 \pm 3.96^{*}\right)\left(0.66 \pm .017^{*}\right)(1.51 \pm$ $0.12^{*}$ ) after treatment with progesterone device in $3^{\text {rd }}, 7^{\text {th }}$ and $9^{\text {th }}$ day respectively when compared with that at the beginning of treatment $(2.75 \pm 0.18)$ in the same groups, as shown in Table (4).

Table (2): Hormonal analysis of FSH in dairy cows treated with progesterone device in zero, $3^{\text {rd, } 7 \text { th }}$ and $9^{\text {th }}$ day of treatment

\begin{tabular}{lrr} 
& \multicolumn{2}{c}{ FSH } \\
Time (day) & Control & Treated \\
& $25.67 \pm 0.80$ & $26.50 \pm 1.34$ \\
zero & $25.50 \pm 0.85$ & $36.83 \pm 1.22^{*}$ \\
3rd & $30.83 \pm 1.58$ & $55.83 \pm 1.29 *$ \\
7th & $24.87 \pm 0.29$ & $25.25 \pm 0.31$ \\
9th & & \\
\hline
\end{tabular}

Table (3): Hormonal analysis of LH in dairy cows treated with progesterone device in zero, $3 \mathrm{rd}, 7 \mathrm{th}$ and 9 th day of treatment.

\begin{tabular}{lll} 
Time (day) & \multicolumn{2}{c}{ LH } \\
& \multicolumn{2}{c}{ Control } \\
zero & $13.94 \pm 0.43$ & Treated \\
3rd & $13.84 \pm 0.64$ & $15.03 \pm 0.342^{*}$ \\
7th & $11.4967 \pm 0.29$ & $15.73 \pm 0.30^{*}$ \\
9th & $12.66 \pm 0.54$ & $11.95 \pm 0.19$ \\
\hline
\end{tabular}

Table (4): Hormonal analysis of progesterone in dairy cows treated with progesterone device in zero, $3^{\text {rd }} 7^{\text {th }}$ and $9^{\text {th }}$ day of treatment.

\begin{tabular}{|c|c|c|}
\hline \multicolumn{3}{|c|}{ Progesterone } \\
\hline \multirow[t]{2}{*}{ Time (day) } & \multicolumn{2}{|c|}{ Group } \\
\hline & Control & Treated \\
\hline zero & $1.29 \pm 0.09$ & $2.75 \pm 0.18$ \\
\hline $3 r d$ & $1.77 \pm 0.15$ & $37.26 \pm 3.96^{*}$ \\
\hline 7th & $0.35 \pm 0.07$ & $0.66 \pm .017^{*}$ \\
\hline 9th & $0.76 \pm 0.09$ & $1.51 \pm .12 *$ \\
\hline
\end{tabular}

The result revealed that in cystic ovary group, 14 of 15 cows showed estrus after treatment with progesterone device as shown in table 4 figure 5 , and only 12 of 14 cows become pregnant as shown in table 4 figure 6 with conception rate $85.7 \%$ as shown in table (5)
The result showed that in smooth inactive ovary group, 12 of 15 cows showed estrus after treatment with progesterone device as shown in table 4 figure 5, and only 7 of 12 cows become pregnant as shown in table (5), with conception rate $58.3 \%$ as shown in table (5).

The result revealed that in persist corpus luteum group, 4 of 10 cows showed estrus after treatment with progesterone device as shown in table (5), and only 3 cows become pregnant as shown in table 4 figure 6 with conception rate $75 \%$ as shown in table (5).

The result revealed that conception rate of cystic ovary group after treatment with progesterone device was higher than that of smooth in active ovary group and persist corpus luteum group after treatment with progesterone device as shown in table 4 and figure 4 , and the conception rate of persist corpus luteum group after treatment with progesterone device was higher than that of smooth inactive ovary group after treatment with progesterone device as shown in table (5)

The result revealed that total conception rate after treatment with progesterone device was $73.3 \%$ as shown in table ( 5).

Table (5): Reproductive performance in dairy cows affected with cystic ovary, smooth in active ovary and persist corpus luteum after treatment with progesterone device.

$\begin{array}{cccccc}\begin{array}{c}\text { Animal } \\ \text { status }\end{array} & \begin{array}{c}\text { No. of } \\ \text { animals }\end{array} & \begin{array}{c}\text { No. of } \\ \text { estrus } \\ \text { cow }\end{array} & \begin{array}{c}\text { No. of } \\ \text { pregnant } \\ \text { cow }\end{array} & \begin{array}{c}\text { No. of } \\ \text { non- } \\ \text { pregnant } \\ \text { cow }\end{array} & \begin{array}{c}\text { Conception } \\ \text { rate }\end{array} \\ \begin{array}{c}\text { Cystic } \\ \text { ovary }\end{array} & 15 & 14 & 12 & 2 & 85.7 \% \\ \begin{array}{c}\text { Smooth } \\ \text { inactive } \\ \text { ovary }\end{array} & 15 & 12 & 7 & 5 & 58.3 \% \\ \begin{array}{c}\text { Persist } \\ \text { corpus } \\ \text { luteum }\end{array} & 10 & 4 & 3 & 1 & 75 \% \\ \text { total } & 40 & 30 & 22 & 8 & 73.3 \%\end{array}$

\section{DISCUSSION}

Reproductive failure is a major source of economic loss in the beef industry. Therefore, the goal of any breeding program is to maximize the number of females that become pregnant. This means that fertility plays a major role in the success of any breeding program. There are several methods by which fertility can be measured one of them is conception rates (number of animals pregnant/number of animals inseminated), In order to make the animal as better productive population, the science has given so many novel reproductive techniques such as estrous synchronization which is one of the most important reproductive techniques 
for improvement of reproduction in livestock. There are many protocols for estrus synchronization and many hormones involved on it, Progesterone is one of the most important hormones which secreted from controlled internal drug release inserts (CIDR) (Perry, 2005; Asnake et al., 2018).

Our study conducted on 40 dairy cattle at Dakahlia Governorate (3.5-5years old) to study the effect of progesterone device insertion in dairy cattle and its effect in fertility.

Results of this study were in line with our expectations and paralleled the findings of other researchers. As expected, the insertion of a progesterone device increased circulating serum progesterone levels to a level higher than mean progesterone concentrations during the pre-treatment cycle.

The effect of progesterone device insertion on serum progesterone:

The present study mirrored a significant increase in progesterone level after treatment with progesterone device compared to control group in $3^{\text {rd }}, 7$ th, and $9^{\text {th }}$ day respectively as shown in table (4).

A significant increase in progesterone concentration in implanted cow's progesterone device might be due to exogenous progesterone and uniform and sustained release of hormone to the vascular system. Hence, the rise of progesterone on the 7th day is obvious due to the effect of progesterone device (Kawate et al., 2004).

Our data was in agreement with NDOSSI et al. (2004) who found that the progesterone concentration significantly increased after progesterone device treatment in Japanese black and Holstein cows that have follicular cyst.

In the same ground Amer and Badr (2006) found that there was marked increases in progesterone concentration of dairy cattle suffer from cystic ovarian disease after CIDR placement. Also Singh et al. (2006) states that there was a significant increase in progesterone level of acyclic sahiwal cows after CIDR insertion.

Similar findings were reported in Egypt by Saad and ELNabawy (2013) who stated that there was a significant increase in serum progesterone at the end of treatment in CIDR-PG treated group, and in the same way Mehni et al. (2012) who studied the effect of CIDR on sixty-four lactating Holestian dairy cows reported that there was a significant increase in serum progesterone after end of treatment. Furthermore Jena et al. (2016) recorded that there was a significant increase in serum progesterone level of jersey crossbred cows treated with CIDR.

The effect of progesterone device insertion on serum FSH \& LH:

Looking to Table (2) there is significant increase in FSH level after treatment with progesterone device in $3^{\text {rd }}$ and $7^{\text {TH }}$ day respectively compared to control group. Also, our study showed a significant increase in LH level after treatment with progesterone device in $1^{\text {st }}$, 3rd and $9^{\text {th }}$ day respectively compared to control group as shown in Table (3).

After progesterone device insertion there is an increased circulatory concentration of progesterone exerted negative feedback on hypothalamus and anterior pituitary. Hence, favoring GnRH, FSH and LH storage. Following termination of progesterone therapy (after CIDR withdrawal by the day 7 after insertion), the rapid drop in circulatory concentration of Progesterone promotes the release of GnRH as the negative feedback of Progesterone was abolished, followed by FSH an LH release with subsequent resumption of ovarian cyclicity. Also, the increased circulatory concentration of progesterone has sensitized the hypothalamic-pituitary system. Likewise, progesterone increased hypothalamus sensitivity to estrogen with subsequent increase in the intensity of heat (Zaabel et al., 2009).

The effect of progesterone device insertion on conception rate:

The present study showed that the conception rate after treatment with progesterone device was $85.71 \%$ for cystic ovary treated group, $58.3 \%$ for smooth inactive ovary treated group, $75 \%$ for persist corpus luteum treated group and total conception rate was $73.3 \%$ as shown in Table(5). In present study 15 dairy cows reported to have cystic ovary when examined by ultrasonography as shown in Table (5), Animals were received progesterone for 7 days with prostaglandin injection at day 7 , at the end of treatment 14 of 15 cows show estrus as shown in Table (5), and only 12 of 14 cows become pregnant as shown in Table (5), with conception rate $85.7 \%$ as shown in Table (5).

Our data reflected that our result was higher than that observed in study of Douthwaite and Dobson (2000) who use progesterone in PRID device for 12 days for treatment of follicular and luteal cyst in 46 Friesian-Holstein cows and recorded conception rate of $28 \%$. Similar findings were reported by Zulu et al. (2003) who say that conception rate for 40 Holstein- Friesian cattle suffer from cystic ovary and treated with PRID inserted intravaginal for 12 days was $53.8 \%$.

In present study 15 dairy cows reported to have smooth in active ovary when examined by ultrasonography as shown in Table (5). Animals were received progesterone for 7 days with prostaglandin injection at day 7 , at the end of treatment 12 of 15 cows show estrus as shown in Table (5). and only 7of 12 cows become pregnant as shown in Table (5) with conception rate $58.3 \%$ as shown in Table (5).

These results can be explained by increase progesterone level after progesterone device insertion intravaginal as it absorbed from vagina to the circulation and as a result progesterone level is increased enough and exerts negative feedback effect on the secretion of GnRH from the 
hypothalamus and releasing $\mathrm{FSH}$ and $\mathrm{LH}$ from the anterior pituitary. Thus, FSH and LH secretion is stopped, and these hormones are reserved in the anterior pituitary. With the removal of CIDR vaginal hormone progesterone is reduced within 6 hours and reaches to the concentration of the base and as a consequence the negative feedback effect is removed, Therefore GnRH is secreted and release of $\mathrm{LH}$ and FSH begins that leads to follicular growth and formation of dominant follicular (Khodabandehloo et al., 2013).

Our results reflected that the conception rate for smooth in active ovary group was higher than that reported with Khalilzadeh et al. (2013) who carried out study on 1000 cow, 200 of them suffered from smooth in active ovaries and divide them to 4 groups each of 50 cows (control, CIDR + estradiol treated group, FSH treated group and gonadoroline treated group) and reported that conception rate for the $1^{\text {ST }}$ group was $29.3 \%$ for $2^{\mathrm{ND}}$ group was $45 \%$, for the $3^{\mathrm{RD}}$ group was $14.7 \%$ and for THE $4^{\text {TH }}$ group was $33.3 \%$.

In the same way our result was higher than that observed in study of Khodabandehloo et al. (2013) who conducted his study on 150 anestrous dairy cows and divided them in to 3 groups (gonadoroline treated group, CIDR +estradiol treated group and $\mathrm{CIDR}+$ gonadoroline $+\mathrm{PGF}_{2} \alpha+$ estradiol group treated group) and reported that the conception rate was $44.4 \%$ in the $1^{\text {st }}$ group, $35.7 \%$ in the $2^{\text {nd }}$ group and $40.9 \%$ in the $3^{\text {rd }}$ group.

Also our result was higher than that reported by Arab et al. (2013) who perform his study on 150 milch anestrus dairy cows divided them in to 3groups (gonadoroline treated group, $\mathrm{CIDR}+$ estradiol treated group $+\mathrm{CIDR}+$ gonadoroline $+\mathrm{PGF}_{2} \alpha$ treated group ) and reported that conception was $37.5 \%$ in the $1^{\text {st }}$ group, $37.2 \%$ in the $2^{\text {nd }}$ group and $34 \%$.

In other way our results mirrored that our conception rate was lower than that that reported with Zaabel et al. (2009) who study the reproductive performance of anestrous buffaloes treated with CIDR -PGF2 $\alpha$ for 14 days and reported that all animals that showed estrus become pregnant with conception rate reach to $100 \%$.

In present study 10 dairy cows reported to have persist corpus luteum when examined by ultrasonography as shown in Table (5).Animals were received progesterone for 7 days with prostaglandin injection at day 7 , at the end of treatment 4of 10 cows show estrus as shown in Table (5) and only 3 of 4 cows become pregnant as shown in Table (5) with conception rate $75 \%$ as shown in Table (5).

\section{Conclusion}

It is obvious that the conception rate of cystic ovary group higher than that of smooth inactive group and persist corpus luteum group and conception rate of persist corps luteum group higher than that of smooth in active group as shown in Table (5). This difference may be attributed to difference in number of treated animals and its body condition score.

\section{Conflict of interest}

Authors declare that they have no conflict of interest

\section{REFERENCES}

Amer H \& Badr A 2006. Hormonal profiles associated with treatment of cystic ovarian disease with GnRH and PGF2 $\alpha$ with and without CIDR in dairy cows. Int J Vet Med, 3: 51-56.

Arab H, Mosaferi S \& Kaveh AA 2013. Comparative evaluation of fertility rate in CIDR and OvSynch+ CIDR treated anestrous dairy cows. European Journal of Experimental Biology, 3: (4), 134-137.

Arthur R 2001. Veterinary control of herd fertility. Veterinary Reproduction and Obstetrics, 8th ed. 511.

Asnake A, Wube A, Abraham J, Yehualaw B \& Hirpa A 2018. Review on Estrous Synchronization in Cow and its Economic Importance. Journal of Reproduction and Infertility, 9: (2), 36-44.

Cooper M 1981. Prostaglandins in veterinary practice. In practice, 3: (1), 3034.

Douthwaite R \& Dobson H 2000. Comparison of different methods of diagnosis of cystic ovarian disease in cattle and an assessment of its treatment with a progesterone-releasing intravaginal device. Veterinary Record, 147: (13), 355-359.

Jena D, Das S, Patra B, Biswal S, Mohanty D \& Samal P 2016. Certain hormonal profiles of postpartum anestrus jersey crossbred cows treated with controlled internal drug release and ovsynch protocol. Veterinary World, 9: (10), 1102

Kawate N, Itami T, Choushi T, Saitoh T, Wada T, Matsuoka K, et al. 2004. Improved conception in timed-artificial insemination using a progesterone-releasing intravaginal device and Ovsynch protocol in postpartum suckled Japanese Black beef cows. Theriogenology, 61: (2-3), 399-406.

Khalilzadeh M, Mosaferi S \& Kaveh AA 2013. Uses of CIDR, FSH and GnRH for treatment of anoestrus syndrome in dairy cow. Bull Environ Pharmacol Life Sci, 2: 27-31.

Khodabandehloo V, Shokorloo SM, Bodaghi F, Reza M, Oshtolagh M \& Tabrizi NN 2013. Evaluation of fertility rate due to CIDR + Heat synch treatment method in anestrous dairy cows. Euro J Zool Res, 2: (5), 43-47.

Lamb GC \& Larson JE 2005. Review of estrus synchronization systems: CIDR. Proc. App. Repro. Strat, 75-84.

Mehni S, Shabankareh H, Kazemi-Bonchenari M \& Eghbali M 2012. The comparison of treating Holstein dairy cows with progesterone, CIDR and $\mathrm{GnRH}$ after insemination on serum progesterone and pregnancy rates. Reproduction in Domestic Animals, 47: (1), 131-134.

NDOSSI D, KAMIMURA S, ANDO T, IWAKUMA A, HAMANA K, MATSUZAKI K, et al. 2004. Efficacy of CIDR treatment against ovarian follicular cysts in cows. Memoirs of the Faculty of Agriculture, Kagoshima University, 39: 45-56.

Pecsok S, McGilliard M \& Nebel R 1994. Conception rates. 1. Derivation and estimates for effects of estrus detection on cow profitability. Journal of Dairy Science, 77: (10), 3008-3015.

Perry G 2005. Factors that influence fertility in natural and synchronized breeding programs. APPLIED REPRODUCTIVE STRATEGIES IN BEEF CATTLE, 149.

Plaizier J, Lissemore K, Kelton D \& King G 1998. Evaluation of overall reproductive performance of dairy herds. Journal of Dairy Science, 81: (7), 1848-1854.

Ravikumar B. 2013. Efficacy of oxytocin and prostaglandins administered at the time of artificial insemination on conception rate of estrus and ovulation synchronized repeat breeder cows. Karnataka Veterinary, Animal and Fisheries Sciences University, Bidar. 
Saad AE-A \& EL-Nabawy Y 2013. Some investigations on cystic ovarian degeneration in dairy cows Theriogenology Department, Faculty of Veterinary Medicine, Zagazig University.

Schumacher M, Guennoun R, Robert F, Carelli C, Gago N, Ghoumari A, et al. 2004. Local synthesis and dual actions of progesterone in the nervous system: neuroprotection and myelination. Growth hormone \& IGF research, 14: 18-33.

Singh H, Luthra R, Khar S \& Nanda T 2006. Oestrus induction, plasma steroid hormone profiles and fertility response after CIDR and eCG treatment in acyclic sahiwal cows. ASIAN AUSTRALASIAN JOURNAL OF ANIMAL SCIENCES, 19: (11), 1566.

Yizengaw L 2017. Review on Estrus Synchronization and Its Application in Cattle. International Journal of Advanced Research in Biological Sciences (IJARBS), 4: (4), 67-76.

Zaabel S, Hegab A, Montasser A \& El-Sheikh H 2009. Reproductive performance of anestrous buffaloes treated with CIDR. Anim Reprod, 6: (3), 460-464.

Zulu VC, Nakao T, Yamada K, Moriyoshi M, Nakada K \& Sawamukai Y 2003. Clinical Response of Ovarian Cysts in Dairy Cows after PRID Treatment. Journal of Veterinary Medical Science, 65: (1), 57-62. 